\title{
Preconcentration Procedure using Vortex Agitator System for Determination of Trace Levels of Cadmium by Flame Atomic Absorption Spectrometry
}

\author{
Mahmoud Chamsaz, Mohammad Eftekhari,*Atefe Atarodi, Saeid Asadpour and Maral Ariani \\ Department of Chemistry, Faculty of Sciences, Ferdowsi University of Mashhad, Mashhad, Iran
}

\begin{abstract}
Um procedimento simples e rápido de microextração líquido-líquido com líquido iônico e agitação vortex (VALLME) foi usado na determinação de quantidades traço de cádmio por espectrometria de absorção atômica com chama (FAAS). O líquido iônico (IL), hexafluorato de 1-hexil-3-metilimidazólio ([Hmim $\left.]\left[\mathrm{PF}_{6}\right]\right)$, foi usado como solvente extractor. Os íons $\mathrm{Cd}^{2+}$ foram complexados com pirrolidina ditiocarbamato de amônia (APDC), e então confinados em pequenas gotas de IL pela intervenção do sistema de agitação vortex. Alguns fatores que influenciam na extração tais como pH, concentração de ligante, quantidade de líquido iônico, tempo de extração e efeito da força iônica foram completamente investigados e otimizados. Sob condições ideais, o limite de detecção foi de $1,1 \mathrm{ng} \mathrm{mL}$ - $^{-1}$ O desvio padrão relativo (RSD) foi 4,3\% para $20 \mathrm{ng} \mathrm{mL}^{-1}$ de cádmio $(\mathrm{n}=10)$, e o gráfico de calibração usando o método de preconcentração foi linear de 5 a $150 \mu \mathrm{g} \mathrm{L} \mathrm{L}^{-1}$, com um coeficiente de correlação de 0,998 . O método proposto foi aplicado com sucesso na determinação de cádmio em amostras de água e folhas de espinafre.
\end{abstract}

A simple and rapid vortex-assisted ionic liquid based liquid-liquid microextraction (VALLME) procedure was used for the determination of trace amounts of cadmium by flame atomic absorption spectrometry (FAAS). Ionic liquid (IL), 1-hexyl-3-methylimidazolium hexafluorophosphate $\left([\mathrm{Hmim}]\left[\mathrm{PF}_{6}\right]\right)$, was used as an extractant solvent. $\mathrm{Cd}^{2+}$ was complexed with ammonium pyrrolidinedithiocarbamate (APDC) and then entered into the fine IL droplets by the assistance of vortex agitator system. Some effective factors that influence the extraction efficiency such as $\mathrm{pH}$, ligand concentration, amount of ionic liquid, extraction time and ionic strength effect were completely investigated and optimized. Under the optimum conditions, the limit of detection (LOD) was $1.1 \mathrm{ng} \mathrm{mL}{ }^{-1}$. The relative standard deviation (RSD) was $4.3 \%$ for $20 \mathrm{ng} \mathrm{mL}^{-1}$ of cadmium $(n=10)$, and the calibration graph using the preconcentration method was linear from 5 to $150 \mu \mathrm{g} \mathrm{L}{ }^{-1}$, with a correlation coefficient of 0.998 . The proposed method was successfully applied for determination of cadmium in water samples and spinach leaves.

Keywords: cadmium, ammonium pyrroldinedithiocarbamate (APDC), ionic liquid, flame atomic absorption spectrometry

\section{Introduction}

Because of the toxicity of cadmium even at low concentration to plants and humans, the quantification of cadmium is very important. ${ }^{1}$ For many years, flame atomic absorption spectrometry (FAAS) has been a standard analytical tool for determination of metals in various matrices owing to its wide application range, simplicity in operation and low cost of analysis. In order to achieve accurate, sensitive and reliable results at trace levels, preconcentration and separation steps are needed prior to analyte determination by FAAS.

*e-mail: meftekhari85@yahoo.com
The most widely used preconcentration methods for the determination of cadmium are cloud point extraction, ${ }^{2-4}$ liquid liquid extraction (LLE) $)^{5,6}$ and solid phase extraction (SPE). ${ }^{7}$ However, these methods often require large amounts of organic solvents, some of which are harmful and contaminate the environment due to their high vapor pressure. The interest in miniaturization of preconcentration methods has led to the introduction of alternative techniques to substitute the conventional liquid-liquid extraction and solid phase extraction procedures. A new solvent minimized extraction method termed liquid-phase microextraction (LPME) ${ }^{8}$ has attracted increasing attention from the analysts for its effectiveness, cheapness, simplicity and cleanup 
ability. A novel modality of LPME technique based on a ternary component solvent system, as an alternative, high-performance and powerful preconcentration method termed dispersive liquid-liquid microextraction (DLLME) has been introduced, which is simple, very fast and inexpensive. ${ }^{9}$ In this method, the extraction is performed between the sample and a cloud of fine extractant drops when an appropriate mixture of extraction and disperser solvents is injected in the aqueous sample. But the amount of disperser solvent used is relatively high, so it is possible that the partition coefficient of the analytes into the extractant phase decreases. Therefore, several methods have been introduced to eliminate the disperser solvents. ${ }^{10,11}$

Recently, considerable interest has been manifested by using room temperature ionic liquids (RTILs) as solvents in a wide range of applications. RTIL is a kind of burgeoning green solvent and can be defined as organic salts that are liquid at or near room temperature. The immiscibility of some ILs with water and their negligible vapor pressure, as well as the high solubility of organic species in them, makes ILs suitable solvents for conventional liquid-liquid extraction. ${ }^{12}$ Yiantzi et al. ${ }^{13}$ introduced a mild emulsification procedure as a new and fast microextraction method termed vortex-assisted liquid-liquid microextraction (VALLME) for the extraction of trace amounts of alkylphenols from water samples. In this method, extractant solvent is introduced to sample solution and the mixture is vigorously shaken with vortex agitator, so that fine droplet of extractant solvent can extract the analyte in short time.

In this work, it was used IL-based VALLME as a simple, low toxicity and fast method coupled to FAAS for determination of trace levels of cadmium. Cadmium preconcentration was mediated by chelation with the ammonium pyrroldinedithiocarbamate (APDC) reagent and an IL (1-hexyl-3-methylimidazolium hexafluorophosphate $\left.\left([\mathrm{Hmim}]\left[\mathrm{PF}_{6}\right]\right)\right)$ was chosen as the extraction solvent to extract a hydrophobic complex. With the shaking of the solution with vortex agitator at $2800 \mathrm{rpm}$ (maximum setting), a vigorous vortex stream is formed in the whole of centrifuge tube which produces very fine droplets of ionic liquid. It is revealed that after formation of fine droplets, the surface area between extraction solvent and aqueous phase (sample) is large. Therefore, the cadmium-APDC complex is extracted into extractant phase $\left([\mathrm{Hmim}]\left[\mathrm{PF}_{6}\right]\right)$ at short time. In this work, it was used ionic liquid ([Hmim] $\left.\left[\mathrm{PF}_{6}\right]\right)$ as extraction solvent because it is safe and has higher density than water, so that separation of extraction solvent and aqueous phase is easy and without loss of analytes. Also, the extraction process compared to single drop microextraction (SDME), ${ }^{14,15}$ in which fast stirring would tend to break up the organic drop, is time-consuming and equilibrium could not be attained after a long time in most cases. ${ }^{14}$ The proposed method is safe, simple and has high extraction efficiency at a short time.

\section{Experimental}

Instrumentation

A Shimadzu AA-670 (Shimadzu, Japan) flame atomic absorption spectrometer equipped with a $100 \mathrm{~mm}$ burnerhead, deuterium background correction and an air-acetylene flame was utilized. A cadmium hollow-cathode lamp (Hamamatsu Photonics, Shizuoka, Japan) at a wavelength of $228.8 \mathrm{~nm}$ was used as a radiation source, operated at $4 \mathrm{~mA}$ with a monochromator spectral bandpass of $0.3 \mathrm{~nm}$. The $\mathrm{pH}$ values were measured with a $\mathrm{pH}$-meter (Metrohm, 632) supplied with a glass-combined electrode. A vortex Gilson mixer (Villiers Le Bel, France) was used for thorough mixing of solutions. Phase separation was assisted using Centurion Scientific centrifuge (Model Andreas Hettich D72, Tuttlingen, Germany).

\section{Reagent and samples}

All reagent used were of analytical grade. All aqueous solutions were prepared in deionized water. A stock solution of $1000 \mathrm{mg} \mathrm{L}^{-1}$ cadmium (II) was prepared by dissolving the appropriate amounts of cadmium chloride (Merck, Darmstadt Germany) in $1 \%$ (v/v) $\mathrm{HNO}_{3}$. Working standard solutions were obtained by appropriate dilution of the stock standard solution. Suprapur ${ }^{\circledR} \mathrm{HNO}_{3}(65 \%$, Merck), Suprapur ${ }^{\circledR} \mathrm{HClO}_{4}\left(70 \%\right.$, Merck) and Suprapur ${ }^{\circledR} \mathrm{H}_{2} \mathrm{O}_{2}(30 \%$, Merck) were used for sample digestion.

The ionic liquid 1-hexyl-3-methylimidazolium hexafluorophosphate ([Hmim] $\left.\left[\mathrm{PF}_{6}\right]\right)$ was synthesized in the Research Institute of Petrochemical Industry (RIPI), Tehran, Iran. Solution of ammonium pyrrolidinedithiocarbamate (APDC, $4 \% \mathrm{~m} / \mathrm{v}$, Merck) was everyday prepared by dissolving $1 \mathrm{~g}$ of APDC in $25.0 \mathrm{~mL}$ ultra-pure water. The $\mathrm{pH}$ values were adjusted by addition of $0.1 \mathrm{~mol} \mathrm{~L}^{-1}$ sodium hydroxide or hydrochloric solutions before use.

Water samples including river, mineral and tap waters were collected from local sources. After sampling, river waters were filtered through $0.45 \mu \mathrm{m}$ filter paper to remove suspended particulate matters. $10 \mathrm{~mL}$ of each sample solutions were used for the analysis after addition of APDC and adjusting its $\mathrm{pH}$ to 3.8 with $\mathrm{HCl}$ solution.

Spinach sample was prepared as follows: $8 \mathrm{~g}$ of dry sample (spinach leaves) were digested with $25 \mathrm{~mL}$ of concentrated $\mathrm{HNO}_{3}$ and $20 \mathrm{~mL}$ of concentrated $\mathrm{HClO}_{4}$ 
on a heating block at low temperature, and then $10 \mathrm{~mL}$ of $\mathrm{H}_{2} \mathrm{O}_{2}(30 \%)$ were added to the solution and heated to near dryness. After dilution to $100 \mathrm{~mL}$ and adjusting of the $\mathrm{pH}$ value to 3.8 , the cadmium content was analyzed according to the recommended procedure.

A mass of approximately $0.1 \mathrm{~g}$ of $\mathrm{ERM}^{\circledR}$-EB325, certified reference material, was dissolved in $20 \mathrm{~mL}$ of $3 \mathrm{~mol} \mathrm{~L}^{-1} \mathrm{HNO}_{3}$. The solution heated at low temperature to near dryness and diluted to $100 \mathrm{~mL}$ with deionized water. The cadmium content was determined according to analytical procedure.

\section{Microextraction procedure}

A volume of $25 \mathrm{~mL}$ of aqueous sample solution containing $100 \mu \mathrm{g} \mathrm{L}^{-1} \mathrm{Cd}^{2+}$ and $0.44 \%(\mathrm{~m} / \mathrm{v})$ of APDC at $\mathrm{pH} 3.8$ was prepared. $10 \mathrm{~mL}$ of this solution were transferred to a screw-cap conical-bottom glass centrifuge tube. The aliquot of $60 \mu \mathrm{L}$ of $[\mathrm{Hmim}]\left[\mathrm{PF}_{6}\right]$ was added to the solution sample and the mixture was then vigorously shaken using a vortex agitator for $5 \mathrm{~min}$ at $2800 \mathrm{rpm}$. With shaking the solution, very fine droplets of ionic liquid were formed through the solution and the cadmium-APDC complex was extracted into the fine droplets of $[\mathrm{Hmim}]\left[\mathrm{PF}_{6}\right]$ at short time. The mixture was then centrifuged for $3 \mathrm{~min}$ at $4000 \mathrm{rpm}$. After this process, the fine droplets of $[\mathrm{Hmim}]\left[\mathrm{PF}_{6}\right]$ were sedimented at the bottom of the conical test tube. Bulk aqueous phase was removed by a syringe and the IL-phase was diluted to $500 \mu \mathrm{L}$ using ethanol and was aspirated to FAAS for determination of cadmium.

\section{Results and Discussion}

The effect of various parameters on the extraction was investigated and the proposed method was applied to determine the amount of cadmium in real water samples.

\section{Effect of $\mathrm{pH}$}

The formation of metal complex and its chemical stability are the two important influence factors for the extraction of metal ions, and the $\mathrm{pH}$ value plays a unique role on metal-chelate formation and subsequent extraction. Cadmium forms stable complexes with APDC over a wide $\mathrm{pH}$ range (1-6), ${ }^{16}$ and can be readily extracted into extraction solvent for FAAS. The effect of $\mathrm{pH}$ on the extraction efficiency was studied in the range of 3-12. The results (Figure 1) demonstrated that the extraction efficiency was maximum and constant at $\mathrm{pH} 3-4$, and then declined at $\mathrm{pH}$ higher than 4 . Thus, the value of $\mathrm{pH} 3.8$ was selected for further experiments.

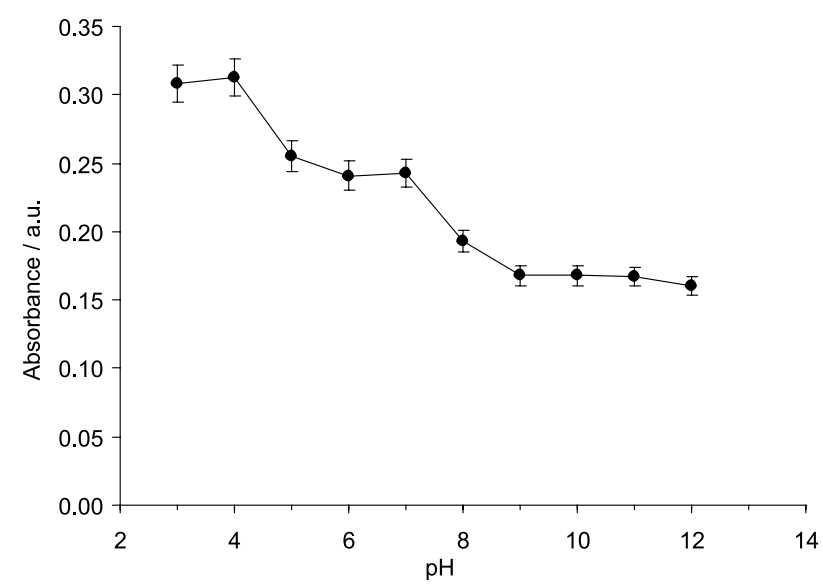

Figure 1. Effect of $\mathrm{pH}$ on the preconcentration and determination of cadmium. Conditions: $100 \mu \mathrm{g} \mathrm{L} \mathrm{L}^{-1} \mathrm{Cd}^{2+}, 0.44 \%(\mathrm{~m} / \mathrm{v})$ of APDC, $60 \mu \mathrm{L}$ $[\mathrm{Hmim}]\left[\mathrm{PF}_{6}\right]$ and extraction time $5 \mathrm{~min}$.

\section{Effect of ligand (APDC) concentration}

In this study, ammonium pyrrolidinedithiocarbamate (APDC) was used as the chelating agent due to the high hydrophobic nature of its metal chelates. According to the results in Figure 2, the recovery of cadmium increased with an increase in ligand concentration, and then remained constant up to the $0.44 \%(\mathrm{~m} / \mathrm{v})$. Thus, the concentration of $0.44 \%(\mathrm{~m} / \mathrm{v})$ was selected as optimum value.

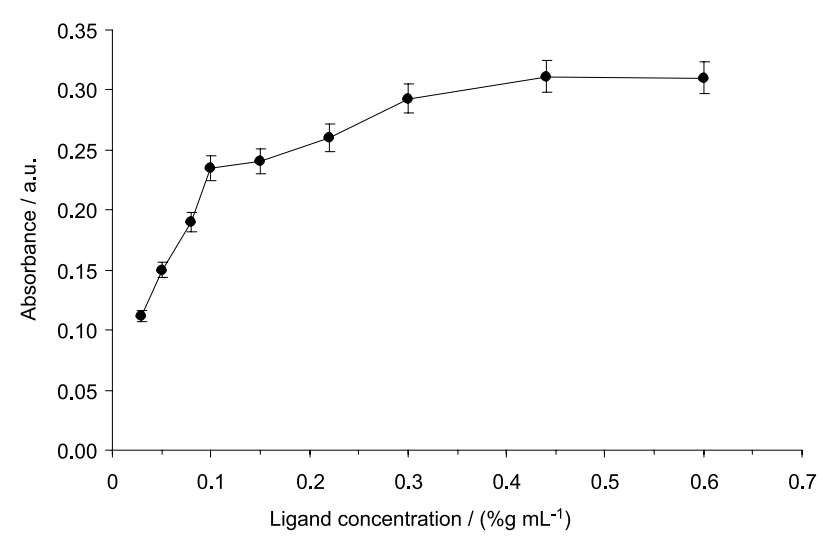

Figure 2. Effect of APDC concentration on the preconcentration and determination of cadmium. Conditions: $\mathrm{pH}: 3.8,100 \mu \mathrm{g} \mathrm{L}^{-1} \mathrm{Cd}^{2+}, 60 \mu \mathrm{L}$ $[\mathrm{Hmim}]\left[\mathrm{PF}_{6}\right]$ and extraction time $5 \mathrm{~min}$.

Effect of amounts of $[\mathrm{Hmim}]\left[\mathrm{PF}_{6}\right]$

The amount of IL is a critical factor to obtain high recoveries of the analyte. The effect of $[\mathrm{Hmim}]\left[\mathrm{PF}_{6}\right]$ was studied in the range of $30-90 \mu \mathrm{L}$, and the results can be seen in Figure 3. By increasing the volume of acceptor phase (ionic liquid), the viscosity of settled phase increased, hence the nebulization process was not effective and therefore the recovery decreased. Thus, the 
aliquot of $60 \mu \mathrm{L}$ of $\left([\mathrm{Hmim}]\left[\mathrm{PF}_{6}\right]\right)$ was employed as the optimum value.

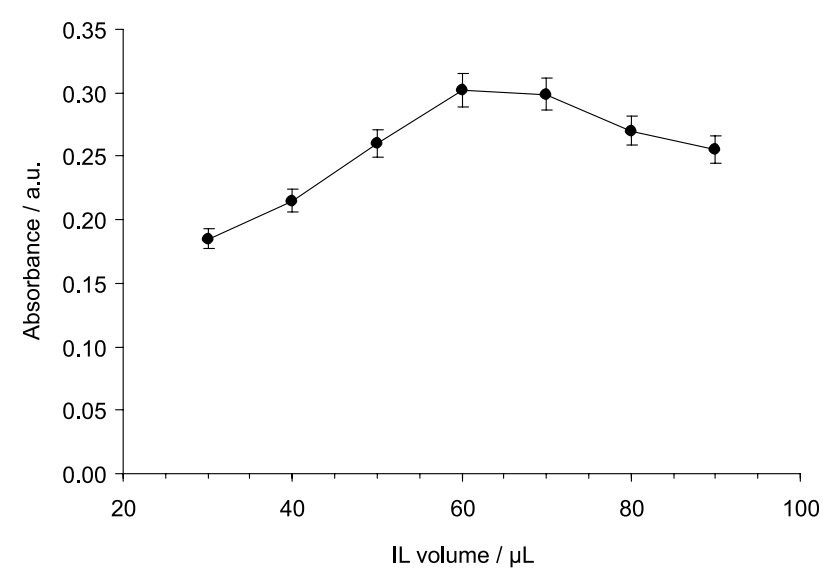

Figure 3. Effect of amounts of RTIL on the preconcentration and determination of cadmium. Conditions: $\mathrm{pH} 3.8,100 \mu \mathrm{g} \mathrm{L}^{-1} \mathrm{Cd}^{2+}, 0.44(\mathrm{~m} / \mathrm{v})$ of APDC and extraction time $5 \mathrm{~min}$.

\section{Effect of the extraction time}

The high viscosity of $[\mathrm{Hmim}]\left[\mathrm{PF}_{6}\right]$ decelerates the mass transfer of the analyte through the interfaces. In this proposed method, the interface between the extraction solvent and the bulk aqueous phases (sample) was enormously enlarged by forming the fine droplet of ionic liquid. Consequently, the equilibrium of the extraction was achieved in a short time. The influence of time was studied within a range of 2-10 min with constant experimental conditions. The results in Figure 4 show that the extraction efficiency of cadmium increased by increasing the extraction time up to $5 \mathrm{~min}$, and then remained constant up to $10 \mathrm{~min}$. Therefore, the time of $5 \mathrm{~min}$ for the extraction time was chosen as the optimum value.

\section{Effect of centrifuge time}

The effect of centrifugation time upon analytical signal was studied in the range of 1-6 min. The results obtained show that at 3 min centrifugation time, the analytical signal was constant indicating complete transfer of IL-phase to the bottom of centrifuge tube. So, a centrifugation time of $3 \mathrm{~min}$ at $4000 \mathrm{rpm}$ was selected for the entire procedure.

\section{Effect of ionic strength}

To evaluate the possibility of salting-out effect, extraction efficiency was studied with the $\mathrm{KCl}$ concentration in the range from $0-1 \mathrm{~mol} \mathrm{~L}^{-1}$, while the other parameters were kept constant. The results showed that the addition of salts had no meaningful effect on the extraction recovery in

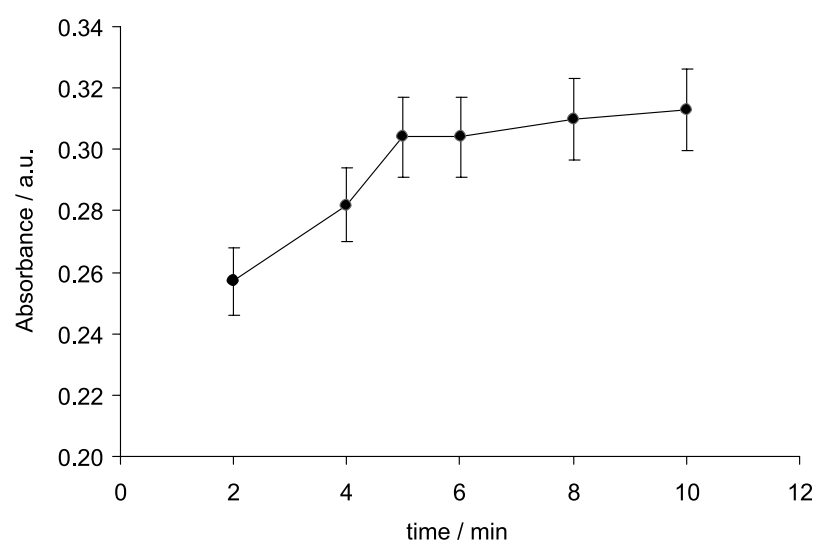

Figure 4. Effect of extraction time on the preconcentration and determination of cadmium. Conditions: $\mathrm{pH} 3.8,100 \mu \mathrm{g} \mathrm{L}^{-1} \mathrm{Cd}^{2+}, 0.44$ (m/v) of APDC and $60 \mu \mathrm{L}[\mathrm{Hmim}]\left[\mathrm{PF}_{6}\right]$.

the studied range. Therefore, all the extraction experiments were performed without the addition of salt.

\section{Effect of co-existing ions}

Various ions were tested as possible interferents. Different amounts of common cations and anions at 100 fold excess were added to the test solution containing $100 \mu \mathrm{g} \mathrm{L}^{-1}$ of cadmium and the proposed procedure was applied. An ion was considered to interfere when its presence produced a variation of more than $5 \%$ in the absorbance of the sample. The results obtained in these experiments (Table 1) demonstrate that the presence of $\mathrm{Zn}^{2+}, \mathrm{Ni}^{2+}, \mathrm{Fe}^{3+}$ and $\mathrm{Cu}^{2+}$ had serious interference in the determination of cadmium. Such interferences were eliminated in the presence of proper masking agents such as $0.05 \mathrm{~mol} \mathrm{~L}^{-1} \mathrm{NaF}$ and $\mathrm{KCN}$ for $\mathrm{Fe}^{3+}$ and $\mathrm{Ni}^{2+}$, respectively. ${ }^{17}$ Interference of $\mathrm{Cu}^{2+}$ and $\mathrm{Zn}^{2+}$ were eliminated in the presence of $0.02 \mathrm{~mol} \mathrm{~L}^{-1}$ ethylenediaminetetraacetic acid disodium salt (EDTA). ${ }^{18}$

\section{Analytical figures of merit}

The preconcentration factor obtained for a sample volume of $10 \mathrm{~mL}$ and a resulting ionic liquid phase volume of $500 \mu \mathrm{L}$ was 20 . From measurements made under the optimum conditions described above, the calibration graph for cadmium was linear in the range of 5 to $150 \mu \mathrm{g} \mathrm{L} \mathrm{L}^{-1}$. The calibration equation is $\mathrm{A}=0.003 \mathrm{C}_{\mathrm{Cd}^{2+}}-0.003$ with a correlation coefficient of 0.998 , where $\mathrm{A}$ is the absorbance for cadmium and $\mathrm{C}_{\mathrm{Cd}^{2+}}$ is the concentration of $\mathrm{Cd}^{2+}$ in $\mu \mathrm{g} \mathrm{L}^{-1}$. The relative standard deviation (RSD, \%) for ten replicate determinations of $20 \mu \mathrm{g} \mathrm{L}^{-1}$ cadmium was $4.3 \%$. The limit of detection (LOD) and of quantification (LOQ) based on $3 \mathrm{~S}_{\mathrm{b}} / \mathrm{m}$ and $10 \mathrm{~S}_{\mathrm{b}} / \mathrm{m}(\mathrm{n}=8)\left(\mathrm{S}_{\mathrm{b}}\right.$ is the standard deviation of the blank and $\mathrm{m}$ is the slope of calibration curve after 
Table 1. Effect of diverse ions on the determination of $100 \mu \mathrm{g} \mathrm{L} \mathrm{L}^{-1}$ of cadmium

\begin{tabular}{lcc}
\hline Interfering ion & $\begin{array}{c}\text { Recovery / } \\
\%\end{array}$ & $\begin{array}{c}\text { Recovery after } \\
\text { elimination / \% }\end{array}$ \\
\hline $\mathrm{Na}^{+}$ & 95.0 & - \\
$\mathrm{K}^{+}$ & 96.3 & - \\
$\mathrm{Ca}^{2+}$ & 95.0 & - \\
$\mathrm{Zn}^{2+}$ & 84.5 & 97.5 \\
$\mathrm{~Pb}^{2+}$ & 96.0 & - \\
$\mathrm{Cu}^{2+}$ & 85.0 & 98.0 \\
$\mathrm{Ni}^{2+}$ & 81.2 & 100.0 \\
$\mathrm{Cr}^{3+}$ & 96.0 & - \\
$\mathrm{Fe}^{3+}$ & 82.0 & 99.0 \\
$\mathrm{Cl}^{-}$ & 100.0 & - \\
$\mathrm{NO}_{3}^{-}$ & 98.8 & - \\
$\mathrm{SO}_{3}^{2-}$ & 97.0 & - \\
$\mathrm{ClO}_{4}^{-}$ & 100.0 & - \\
$\mathrm{CH}_{3} \mathrm{COO}^{-}$ & 98.0 & - \\
\hline
\end{tabular}

extraction), were 1.1 and $3.7 \mu \mathrm{g} \mathrm{L} \mathrm{L}^{-1}$, respectively. The enhancement factor (EF) was 31, which was calculated by using the ratio between the slopes from calibration graphs obtained with and without the preconcentration step. The sensitivity of the proposed method for determination of cadmium based on 0.0044 was $2.47 \mu \mathrm{g} \mathrm{L}^{-1}$.

\section{Application to real samples}

The accuracy of the proposed method was verified with the analysis of the certified reference material (CRM), ERM ${ }^{\circledR}-\mathrm{EB} 325$, with certified $\mathrm{Cd}^{2+}$ content of $94.7 \pm 2.5 \mu \mathrm{g} \mathrm{g}^{-1}$. Using the method developed in this study, the $\mathrm{Cd}^{2+}$ content found in the CRM was $91.3 \pm 1.4 \mu \mathrm{g} \mathrm{g}^{-1}$ (mean \pm standard deviation based on three replicate analysis). Also, the proposed method was applied to determine $\mathrm{Cd}^{2+}$ ions in natural water samples (tap, river and mineral water) and spinach leaves. In order to demonstrate the validity of this method, recovery experiments were also carried out by spiking different amounts of cadmium before any pretreatment. The results presented in Table 2 show that the proposed procedure could be satisfactorily used for the analysis of real samples.

Table 2. Results (mean \pm standard deviation based on three replicate analysis) for cadmium determination in real samples

\begin{tabular}{lccc}
\hline Sample & $\begin{array}{c}\text { Spiked / } \\
\left(\mu \mathrm{g} \mathrm{L}^{-1}\right)\end{array}$ & $\begin{array}{c}\text { Found / } \\
\left(\mu \mathrm{g} \mathrm{L}^{-1}\right)\end{array}$ & $\begin{array}{c}\text { Recovery / } \\
\%\end{array}$ \\
\hline Tap water $^{\mathrm{a}}$ & 0 & $\mathrm{nd}^{\mathrm{b}}$ & - \\
River water $^{\mathrm{c}}$ & 70 & $71.1 \pm 0.7$ & 101.6 \\
River water $^{\mathrm{d}}$ & 0 & $9.0 \pm 0.2$ & - \\
& 70 & $80.5 \pm 1.0$ & 101.9 \\
River water $^{\mathrm{e}}$ & 0 & $11.1 \pm 0.3$ & - \\
& 0 & $82.0 \pm 0.9$ & 101.1 \\
Mineral water & 70 & $5.6 \pm 0.2$ & - \\
& 0 & $76.0 \pm 0.8$ & 100.5 \\
Spinach sample & 0 & $\mathrm{nd}$ & - \\
& 30 & $71.5 \pm 0.7$ & 102.1 \\
& 70 & $35.5 \pm 0.2$ & - \\
& 0.5 & 97.3 \\
\hline
\end{tabular}

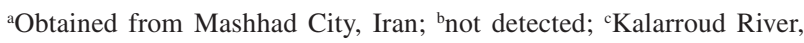
Mazandaran Province, Iran; ${ }^{\mathrm{d}}$ Golnabdarre River, Mazandaran Province,

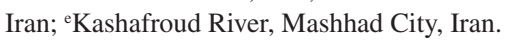

\section{Comparison of VALLME with other methods}

Determination of cadmium by the VALLME method was compared with other preconcentration methods and the results are shown in Table 3. As it is evident, the VALLME method has better dynamic range (5-150 $\mu \mathrm{g} \mathrm{L}-1)$, less toxicity (using ionic liquid as extraction solvent) and simplicity compared to some reported methods. ${ }^{19-22}$

Table 3. Comparison of VALLME with other methods for cadmium determination

\begin{tabular}{|c|c|c|c|c|c|}
\hline Method & $\begin{array}{l}\text { LOD / } \\
\left(\mu g \mathrm{~L}^{-1}\right)\end{array}$ & $\mathrm{RSD} / \%$ & $\mathrm{EF}$ & $\begin{array}{c}\text { Dynamic range / } \\
\left(\mu \mathrm{g} \mathrm{L}^{-1}\right)\end{array}$ & Reference \\
\hline Solid phase extraction & 0.19 & - & 18 & $5-35$ & 19 \\
\hline Solid phase extraction-in flow injection system & 1.70 & 2.4 & - & $5-50$ & 20 \\
\hline Flow injection wetting-film extraction system & 0.70 & 3.9 & 35 & $1.5-45$ & 21 \\
\hline Ultrasound-assisted microextraction & 0.91 & $1.6-2.6$ & 13 & $10-600$ & 22 \\
\hline Cloud point extraction & 0.50 & 3.4 & 27 & $1.7-20$ & 23 \\
\hline Dispersive liquid-liquid microextraction & 0.40 & $1.9-2.7$ & 55 & $5-100$ & 24 \\
\hline Hollow fiber renewal liquid membrane (HFRLM) procedure & 1.50 & 4.0 & - & $5-30$ & 25 \\
\hline VALLME & 1.10 & 4.3 & 31 & $5-150$ & this work \\
\hline
\end{tabular}

LOD: limit of detection; RSD: relative standard deviation; EF: enhancement factor. 
Although the other reported methods ${ }^{23-25}$ have better dynamic range, limit of detection (less than $1.1 \mu \mathrm{g} \mathrm{L}-1$ ) and lower relative standard deviation (less than 4\%), VALLME has a better enhancement factor (except for flow injection wetting-film extraction system ${ }^{23}$ and relatively high rapidity. Again, because our method has low toxicity, it is possible to state that it is green.

All these results indicate that ionic liquid VALLME is a relatively rapid, environmentally friendly and simple technique that can be used for preconcentration of metal ions like cadmium in real samples.

\section{Conclusion}

Vortex-assisted ionic liquid based liquid-liquid microextraction (IL-VALLME) preconcentration method is an effective method for trace level determination of cadmium. This method is accurate, safe and requires short extraction time. The proposed technique can be successfully applied to environmental samples for the determination of traces of cadmium.

\section{Acknowledgement}

The authors wish to thank Ferdowsi University of Mashhad for the financial support of this work.

\section{References}

1. Schwartz, G. G.; Reis, I. M.; Canc. Epidemiol. Biomarkers Prev. 2000, 9, 139.

2. Ghaedi, M.; Shokrollahi, A.; Niknam, K.; Soylak, M.; Cent. Eur. J. Chem. 2009, 7, 148.

3. Afkhami, A.; Madrakian, T.; Siampour H.; J. Hazard. Mater. 2006, 138, 269.

4. Rezende, H. C.; Nascentes, C. C.; Coelho, N. M. M.; Microchem. J. 2011, 97, 118.

5. Wang, J.; Hansen, E. H.; Anal. Chim. Acta 2002, 456, 283.

6. Anthemidis, A. N.; Zachariadis, G. A.; Farastelis, C. G.; Stratis, J. A.; Talanta 2004, 62, 437.
7. Pourreza, N.; Ghanemi, K.; J. Hazard. Mater. 2010, 178, 566.

8. Liu, H.; Dasgupta, P. K.; Anal. Chem. 1996, 68, 1817.

9. Berijani, S.; Assadi, Y.; Anbia, M.; Hosseini, M. R. M.; Aghaee, E.; J. Chromatogr., A 2006, 1123, 1.

10. Molaakbari, E.; Mostafavi, A.; Afzali, D.; J. Hazard. Mater. 2011, 185, 647.

11. Shah, F.; Kazi, T. G.; Naeemullah; Afridi, H. I.; Soylak, M.; Microchem. J. 2012, 101, 5.

12. Anderson, J. L.; Armstrong, D. W.; Wei, G. T.; Anal. Chem. 2006, 78, 2892.

13. Yiantzi, E.; Psillakis, E.; Tyrovola, K.; Kalogerakis, N.; Talanta 2010, 80, 2057.

14. Jeannot, M. A.; Cantwell, F. F.; Anal. Chem. 1997, 69, 235.

15. Ahmadi, F.; Assadi, Y.; Milani Hosseini, S. M. R.; Rezaee, M.; J. Chromatogr., A 2006, 1101, 307.

16. American Public Health Association; Standard Methods for the Examination of Water and Wastewater, $19^{\text {th }}$ ed.; APHA/AWWA/ WEF: Washington, 1995.

17. Tajik, S.; Taher, M. S.; Desalination 2011, 278, 57.

18. Molaakbari, E.; Mostafavi, A.; Afzali D.; J. Hazard. Mater. 2011, 185, 647.

19. Costa, L. M.; Ribeiro, E. S.; Segatelli, M. G.; Nascimento, D. R.; Oliveira, F. M.; Tarley, C. R. T.; Spectrochim. Acta, Part B 2011, 66, 329.

20. Bianchin, J. N.; Martendal, E.; Mior, R.; Alves, V. N.; Araújo, C. S. T.; Coelho, N. M. M.; Carasek, E.; Talanta 2009, 78, 333.

21. Sanchez Rojas, F.; Bosch Ojeda, C.; Cano Pavon, J. M.; Anal. Methods 2011, 3, 1652.

22. Luciano, R. M.; Bedendo, G. C.; Carletto, J. S.; Carasek, E.; J. Hazard. Mater. 2010, 177, 567.

23. Adam, I. S. I.; Anthemidis, A. N.; Talanta 2009, 77, 1160.

24. Ma, J. J.; Du, X.; Zhang, J. W.; Li, J. C.; Wang, L. Z.; Talanta 2009, 80, 980.

25. Baliza, P. X.; Cardoso, L. A. M.; Lemos, V. A.; Environ. Monit. Assess. 2012, 184, 4455.

Submitted: April 22, 2012 Published online: August 15, 2012 